\title{
Singular Memory or Institutional Memories? Towards a Dynamic Approach
}

Jack Corbett, Dennis Grube, Heather Lovell and Rodney Scott

*A slightly amended version of this article is forthcoming in Governance

\begin{abstract}
The ability of the civil service to act as a reservoir of institutional memory is central to the pragmatic task of governing. But, there is a growing body of scholarship that suggests the bureaucracy is failing at this core task. In this article we distinguish between two different ways of thinking about institutional memory: one "static" and one "dynamic". In the former, memory is singular and held in document form, especially by files and procedures. In the latter, memories reside with people and are thus dispersed across the array of actors that make up the differentiated polity. Drawing on four policy examples from three countries we argue that a more dynamic understanding of the way institutions remember is both empirically salient and normatively desirable. We conclude that the current conceptualisation of institutional memory needs to be recalibrated to fit the types of policy learning practices required by modern collaborative governance.
\end{abstract}

Keywords: institutional memory, institutional memories, new public management (NPM), collaborative governance, network governance, policy learning

\section{Introduction}

Democratic governance is characterised by the regular rotation of elected leaders. Amidst this inevitable churn, the civil service is expected to act as the repository of received wisdom about past policies, including assessments of what works and what doesn't (Richards and Smith 2016). There is a growing body of scholarship that questions whether declining institutional memory allows modern bureaucracies to fulfil this function adequately (Pollitt 2000; 2007; 2008; 2009; Lindquist and Eichbaum 2016; Wettenhall 2011; Rhodes and Tiernan 2014; Stark 2017). The argument is that a decline in institutional memory has occurred against a background of wider changes in the governance environment, including the advent of new public management (NPM), digital transformation, the influence of ministerial advisers, the 24-hour news cycle and its impact on the increasing pace of government, and changing 'bargains' between political executives and the bureaucracy (Marsh and Rhodes 1992; Rhodes 1997; Hood and Lodge 2006; Marsh 2011). Increasingly, scholars characterise policy change as being steered by networks, with the siloed workings of departments being dragged into more collaborative ways of working across government and in co-production with the private sector and community organisations (Alford and O’Flynn 2012; Bartenberger and Sześciło 2016; Osborne 2009). 
In this new environment no single actor or organisation is capable of retaining the full memory of a process of which they were simply one part. Rather, memories are necessarily dispersed. The key question for both academics and policy makers is how can institutional memory continue to be captured when it is distributed so widely? If past ways of institutionalising memory are no longer sufficient in the fast and continuous information flows required for modern governance, then we need conceptual tools capable of seeing memory as something more than simply a file stored in a single location.

In this article we argue that one of the key reasons why institutional memory has become problematic is that it has been conceptualised in a 'static' manner more in keeping with an older way of doing government. This practice has assumed that knowledge on a given topic is held centrally (by government departments) and can be made explicit for the purpose of archiving. But, if government doesn't actually work this way then we shouldn't expect it to remember this way either. Instead of static repositories of summative documents holding a singular 'objective' memory, we propose a more 'dynamic' peoplecentred conceptualisation that sees institutional memory as a composite of intersubjective memories open to change. This draws to the fore the role of actors as crucial interpreters of memory, combining the documentary record with their own perspectives to create a story about the past.

The article therefore makes three distinct contributions:

Conceptually: we argue for a shift from a static singular memory to a dynamic model of intersubjective memories more in keeping with the processes and practices of modern collaborative governance;

Empirically: we draw on extensive primary data collected through four in-depth policy examples from three countries, including 40 interviews, to demonstrate the dynamic nature of modern policy memories; and

Methodologically: we extend recent actor-centred approaches to institutional memory (e.g. Rhodes and Tiernan 2014) by undertaking an explicitly comparative approach.

In the sections that follow, we first review the existing literature on institutional memory to illustrate how arguments about its decline hinge on a 'static' conceptualisation of the past; knowledge that is objectively 'out there' waiting to be reordered and retrieved. Second, we consider what a more 'dynamic' conceptualisation of institutional memory might look like, drawing on the arguments of Czarniawska (1997) and Linde (2008) in particular. ${ }^{1}$ In doing so we differentiate between policy learning and institutional memory,

${ }^{1}$ Our thanks to Anne Tiernan for alerting us to Linde's work. 
with the former concept primarily concerned with increasing or improving knowledge about policy while the latter seeks to explain how knowledge becomes embedded within institutional processes and practices. Third, we outline the methods and data used to substantiate these claims. Fourth, we present our empirical findings to demonstrate the validity of our conceptual claims. In the conclusion, we draw together the empirical findings with the earlier theoretical insights to propose ways in which memory might be better operationalised as a spectrum of activity, combining the security of written documentation with the dynamism of living memory within and across organisations.

\section{Institutional Memory: Definitions, Purpose, and the Decline Thesis}

The idea that memory is central to the task of governing is hardly new. Lindblom's (1959) model of 'muddling through' highlights that policies tend to be developed incrementally, and in this sense institutional memories are important for enabling 'tried and tested' policies from the past to resurface and, with small modifications, be used again. Similarly, there are now well-established theoretical perspectives on historical institutionalism and path dependency which argue that the past constrains the future (Pierson 2000 and 2004; Lowndes and Roberts 2013; Bell 2011). The recent emergence of more actor-centred variants of institutionalism foreground the power of agents in creating change through ideas and discourse, giving shape to how individuals in government perceive their work (Bell 2011; Bevir and Rhodes 2010; Hay 2011; Rhodes 2011; Schmidt 2008). This has particular resonance for the study of institutional memory. Whether through the conscious agency of actors, or some more formalised organisational structure, what institutions remember effects the way they frame future tasks.

As this work illustrates, institutional memory has been implicitly central to the study of public administration for decades, but it is only recently that scholars have turned to its explicit study in a systematic way (Pollitt 2000; 2007; 2008; 2009; Wettenhall 2011; Rhodes and Tiernan 2014). This emerging literature has both empirical and normative aims. Empirically scholars have sought to understand and explain the ways policy makers remember the past. The normative claim is that institutional amnesia is a barrier to policy learning. That is, if the past is neglected then governments are destined to repeat failures (see Pollit 2008; King and Crewe 2013). The decline thesis is therefore more than an intellectual enterprise; it seeks to instantiate change to the processes and practices of remembering in order to improve policymaking.

The scholar who has done the most to advance the recent discussion of institutional memory in government is Christopher Pollitt (2000; 2007; 2008; 2009). Pollitt cites a range of both endogenous and exogenous factors as contributing to the decline of institutional memory. He suggests that high rotation of staff, changes in IT systems which prevent proper archiving, regular organisational restructuring, rewarding management skills above all others, and adopting new management 'fads' as they become popular provide a perfect 
recipe for loss of institutional memory within organisations (Pollitt, 2008: 173). According to Pollitt, the managerialist attitudes present in NPM that favour constant change has encouraged the kind of 'contempt for the past' that underpins failures in record keeping (Pollitt, 2009: 207).

Whilst Pollitt has been the most prolific contributor to academic arguments in favour of restoring institutional memory, he is not alone in lamenting its decline. Wettenhall (2011: 86) similarly identifies the NPM environment as enabling the factors that drive institutional memory loss, including cost cutting drives, record keeping functions developing a status as 'non-core' or unimportant, and frequent reorganising and changes to the workforce and downsizing. Using the case of Australia, Rhodes and Tiernan (2014: 214) suggest that geography has further compounded the problem of diminishing institutional memory, with the move to new Parliament House in 1988 isolating ministers and the prime minister from the public service.

Despite increasing levels of interest in its role and in the causes of its alleged demise, institutional memory has thus far defied easy scholarly definition, with continuing ambiguity about what it is, and what it's for. The first stumbling block is the need to differentiate between learning and memory. Bennett and Howlett define policy learning very broadly as '...the general increase in knowledge about policies' (Bennett and Howlett 1992, 288; for a fuller discussion see Dunlop and Radaelli 2013). Is there then a continuum from learning to memory - with an inflection point where accumulated knowledge turns into something we could call memory? The literature remains unclear on this.

Equally, there is no definitive point of disjunction between those components of learning and memory that are essentially documentary in nature and those that reside in the experience of individuals. Individuals build shared memories in which documents and their own experience combine to create a story of what happened. These stories are held at the level of organisations, and are given institutional form by the ways they help to shape future action as actors recall these past stories when faced with a new challenge. This helps to explain why the literature has not produced a definitive distinction between 'organisational memory' and 'institutional memory', with many authors using the terms almost interchangeably. For instance, Pollitt (2009) often uses 'organisational memory', defined as '...consisting of a range of "storage" locations... the experience and knowledge of the existing staff: what is "in their heads" ...the technical systems, including electronic databases and various kinds of paper records...The management system... and the norms and values of the organizational culture' (2009: 202).

To resolve these conceptual shortcomings, we draw on the pioneering work of Linde and Czarniawska. Linde's $(2009,11)$ work on institutional memory and narrative foregrounds the role of interpretation by suggesting that memories are 'representations of the past'. As she puts it, '[i]nstitutions certainly make efforts to preserve aspects of their 
past, to find and retrieve some of these representations of the past, and to use them in the present to influence the future. Let us call it memory ...' (Linde 2009, 11). She then differentiates the different 'modes of remembering' that are available. '...[T] here exist a spectrum of modes of remembering within institutions. These range from strategies relying on individual human memory and transmissions from human to human, through archival and computer storage of documents... to organisational policies and procedures and even physical infrastructure' (Linde 2009, 11).

Uniting Linde and Pollitt's approaches to institutional memory are two things. Firstly, an emphasis on knowledge (and hence the close link to studies of policy learning). We can read Linde as viewing memory and learning as inextricably inter-related, operating as an iterative duality. We therefore define memories as the 'representations of the past' that actors draw on to narrate what has been learned when developing and implementing policy. When these narratives are embedded in processes they become 'institutionalised'. It is this emphasis on embedded narratives that distinguishes institutional memory from policy learning and its emphasis on increasing or improving knowledge about policy. Institutional memory may facilitate policy learning but equally 'static' memories may prohibit genuine adaptation and innovation. As a result, while there is an obvious affinity between the two concepts it is imperative that they remain distinct avenues of inquiry. Policy learning has unequivocally positive connotations that are echoed in some conceptualisations of institutional memory (i.e. Pollitt). But, equally, memory (at least in a 'static' form) can be said to provide administrative agents with an advantage over political principals (think of the satirical Sir Humphrey of Yes Minister fame).

Secondly, this work draws attention to the different forms that institutional memory takes - residing within people, documents, policies and procedures and so on. Recognition of the different forms memories take highlights the significance of communication in the processes and practices of remembering. Here, we turn to Czarniawska's work on knowledge, narrative and organizational identity. Drawing on literary theory in particular, Czarniawska's $(1997,6)$ shifts the emphasis from knowledge as something that is 'out there' waiting to be discovered to the forms in which knowledge is cast and the effects this has on institutions: 'The narrative mode of knowing consists in organizing experience with the help of a scheme assuming the intentionality of human action' (Czarniawska 2004, 18). The point, from our perspective, is that memory is more than a collection of facts and figures; it functions as a dramatized story. It has a plot. It has characters. There are different genres. But all have a narrative arc that operates to sequence key events and decisions which then take shape as stories masquerading as memories. As Czarniawska puts it, "The company suffered unprecedented losses" and "the general manager was forced to resign" are two events that call for interpretation ... the difference lies in the temporal ordering, and suggested connection between the two' (Czarniawska 1997, 14). In other words, '...some 
kind of causality may be inferred but it is crucial to see that narrative, unlike science, leaves open the nature of the connection' (Czarniawska 2004, 18).

In relation to our arguments here, the key point is that institutionalising memoryembedding representations of the past in processes -is not something that only occurs after a given policy decision is taken, or a policy implemented, but rather actors are continuously engaged in this dynamic practice. As Czarniawska (1997, p. 24) highlights, faced with the task of accounting for their actions, actors justify themselves by employing their knowledge of the institution and its past in narrative form to explain why they did what they did. Like Linde, Czarniawska argues that repertoires vary, but the goal - to create a narrative that is as coherent as possible - is similar to all individuals and the institutions they inhabit. Indeed, we might go as far as to claim that it is the appearance of a coherent narrative that constitutes the institution. Institutional memory is thus, for Czarniawska, a never ending form of storytelling in which the key institutional questions are: who are we; what do we do; and how do we typically operate.

If institutional memory operates as a form of storytelling that links past policy learnings with present policy problems, it is reasonable to then ask whether its possible to distinguish between 'true' and 'false' memories in a narrative mode of knowing. Again we build on Czarniawska who argues that in a narrative-mode, the plausibility of the knowledge claim is determined by the plot. Thus:

A narrative which says 'The top managers resigned and then it rained a whole week' (i.e. a narrative with no plot or an incomprehensible plot) will need some additional elements to make sense of it, even though the two events and their temporal connection may well be true and correct in themselves (Czarniawska 2004, 18).

In which case, a narrative approach to knowledge and memory that emphasises its dynamic nature does not mean abandoning agreed facts or truths, but rather recognises that they cannot speak for themselves. In being spoken, however, they reveal a polyphony of interpretations, sub-plots and rival accounts. It is these rival accounts that illustrate the dynamic nature of institutional memory.

Finally, having thus established a working conception of institutional memory that emphasises its narrative, story telling form, it is also necessary to examine its purpose what is institutional memory for and what impact can it have on an organisation? Walsh and Ungson (1991) distinguish between several different functions of institutional memory, including learning, impacts on organisational culture, and the entrenchment of existing power bases. Pollitt's thesis emphasises (and laments the decline of) the positive effect of memory on decision-making. Early literature on institutional memory described negative and positive effects of remembering the past. Those emphasising negative effects suggested that memories limit the range of solutions that an institution will consider (March 1972; 
Nystrom and Starbuck 1984). Authors emphasising positive effects suggested that memories of past events can result in improved decision-making through better anticipating causal associations (Duncan and Weiss, 1979; Schon, 1983). For the most part, however, these authors relied on a 'static' conceputalisation of institutional memory. We venture that a more 'dynamic' conceputalisation has the potential to mitigate some of the negatives and accentuate some of the advantages that these scholars identify.

\section{NPM and Collaboration - Towards a Dynamic View of Memory in Institutional Contexts}

Existing work has highlighted the need for governments to rethink memory, not simply as a record of the past but as a vital tool for building the policy future. But, with the exception of Linde and Czarniawska, to date the proposed solutions to the perceived decline in institutional memory largely involve recourse to older ways of doing government. Even if returning to the past were desirable, we argue that it is no longer feasible because of the dispersed nature of modern governance (Hendriks 2009; Marsh 2011; Bouckaert 2017). Working across agency boundaries is now 'essential to the core business of government' (Carey and Crammond, 2015) and 'the new normal' (Sullivan, 2015). To build on Pollitt's work, we therefore argue that a dynamic conception of institutional memory must include knowledge that is both scattered between organisations and difficult to express. Ontologically, we follow Linde and Czarniawska in a shift away from the recording of objective 'facts' on a paper file, towards an understanding of institutional memories as dynamic 'live conversations.' Epistemologically, this means a shift to allow for the construction and interpretation of multiple memories rather than one agreed memory such as that which might be rendered by a set of minutes. To capture this, we need to build a new way of conceptualising institutional memories from the ground up. These shifts are outlined in Table 1 below.

TABLE 1: THE SPECTRUM OF INSTITUTIONAL MEMORIES

\section{'Static' Institutional Memory}

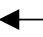

Located in individual

departments

Summative - end-of-project

evaluation

Focussed on the civil service

Takes a material form: paper

or digital files

\section{'Dynamic' Institutional Memories}


combination of fresh

perspectives, individual agency

and shared stories.

As we illustrate in our empirical discussion below, current practitioners provide evidence which supports Pollitt's contentions around a decline in institutional memory, but remain unsure about how the decline can be arrested. Stopping position churn, re-inserting public servants into ministerial offices, and reinvigorating better record management practices and other decisions would arguably still not enable governments to capture distributed memory. Instead, thinking of memories as 'living conversations' spread across a hybrid of actors offers opportunities for breaking down this kind of individualised atomisation of memory, and suggests new avenues for retaining it.

A dynamic conceptualisation thus emphasises how the past is actually communicated, rather than merely recorded, with the telling of stories playing a central role (Czarniawska 1997; Linde 2008; Rhodes 2011; Stark 2017). For example, Linde argues that 'occasions' (such as staff functions, speeches etc.) represent environments in which stories about an organisation's history, purpose and trajectory are rehearsed and internalised. They represent the moments when 'the process of institutional remembering can be deliberately altered' (Linde, 2008: 222). She suggests while an institution keeps existing, new stories will be added to the collection of disasters (what not to do), triumphs (what to do), changes in direction, and new 'heroes' will emerge to act as role models for others to follow (Linde, 2008: 222).

A more dispersed form of memory does not of course guarantee dynamism. It's theoretically possible for even a widely dispersed memory to remain trapped within locked documentary files, or indeed untold by individuals, and thus held mute in multiple places by dispersed actors. What causes static memory to become dynamic is it's constant retrieval and reavaluation through social interaction between actors as they translate static documents into living memories. This reflects the nature of the spectrum outlined in Table 1 as being relatively fluid rather than a stark binary. For example, government reports frequently have a narrative grow around them that becomes embedded as part of the story. As we discuss below in our case study on the roll-out of smart meters in Victoria, key documents like the auditor-general's report remain an integral part of the memory of that policy implementation process and the 'story' of failure that is told about it, acting to reinforce the credibility of the story.

This emphasis on storytelling offers an inherently iterative conceptual key for unlocking a more dynamic form of institutional memory. It draws our attention to actors as the key disseminators and repositories of memory. A dynamic approach to institutional memories therefore conceptualises storytelling as a social phenomenon that can be 
exchanged both within and between organisations. It conceives of memories as the intersubjective retelling of events that imbues them with meaning. In which case, remembering is not so much about retrieving facts and files, but received traditions; ways of seeing the world and acting in it.

\section{Methods and Dataset}

If memories are fundamentally about story-telling, and this way of thinking has empirical salience in highly networked and differentiated policy environments, then evaluating whether current practices and processes of remembering differ from the more static conceptualisation requires a particular approach to collecting and analysing data. In particular, the emphasis on storytelling invokes the main precepts of the discursive turn in the social and policy sciences (Fischer 2003; Stone 2012; Schmidt 2008 and 2010). It also moves us away from more traditional variants of historical institutionalism towards more 'actor-centred' approaches (e.g. Bell 2011) and what Bevir and Rhodes (2010) term 'situated agency' (cf. see Corbett and Howard 2017; Elston 2014; Smullen 2010). The point of this distinction is that by recognising the plurality of actors and their memories, the latter approach offers a more dynamic rendering than the former static view.

Many of Pollitt's (2008) empirical observations on institutional memory are based on British, Australian, and New Zealand cases. Following Pollitt, we draw our examples from the same jurisdictions, both to hold the Westminster system of government constant (see Rhodes, Wanna and Weller 2009) and to test whether a more dynamic version of institutional memory could mitigate against the declines that Pollitt finds in those jurisdictions. We ask how each policy: 1) built on past ways of knowing; and 2) is represented now, including the methods by which representations of the past have been embedded within institutionalised processes. Aside from being Westminster democracies, our examples are 'most different' (Lijphart 1971). We investigate four different policies from three countries. We have two national-level examples in Britain and New Zealand, but then also select two sub-national examples in Australia. This allows us to control for whether memories are more easily sustained in smaller jurisdictions than in large ones. Two of the examples are primarily undertaken by government departments whereas the other two are 'collaborative' in the sense that they involve both government and non-government actors. A 'most different' design allows us to generalize about any similarities that occur across the policy areas.

In each of our four examples we drew on a combination of in-depth interviews with key actors and the public record to both reconstruct the process by which the policy in question was made, and probe how memory was captured in each instance. The interviewees in each example were deliberately chosen in order to ensure both a vertical and horizontal spread. Vertically, we set out to capture the insights of heads of agency and the mid-level civil servants undertaking the substantive policy work. Horizontally, in the two 
examples of specifically hybrid collaborations - in Victoria and the United Kingdom - we interviewed not just government actors, but also representatives from collaborating organisations to see whether their 'memories' of a particular policy process matched or not, and to compare policy learning.

TABLE 2: Dataset

\begin{tabular}{|c|c|c|c|}
\hline Policy examples & Dataset & National or Sub/National & $\begin{array}{l}\text { Collaboration } \\
\text { across government; } \\
\text { or between } \\
\text { government and } \\
\text { external actors }\end{array}$ \\
\hline $\begin{array}{l}\text { Zero Carbon } \\
\text { Homes in the } \\
\text { UK }\end{array}$ & $\begin{array}{l}10 \text { interviews, public } \\
\text { documents, } \\
\text { memoirs }\end{array}$ & National & $\begin{array}{l}\text { Government and } \\
\text { External Actors }\end{array}$ \\
\hline $\begin{array}{l}\text { The Justice } \\
\text { Sector in New } \\
\text { Zealand }\end{array}$ & $\begin{array}{l}10 \text { interviews and } \\
\text { public documents }\end{array}$ & National & Across Government \\
\hline $\begin{array}{l}\text { Family Violence } \\
\text { Action Plan- } \\
\text { Tasmania, } \\
\text { Australia }\end{array}$ & $\begin{array}{l}9 \text { interviews and } \\
\text { public documents }\end{array}$ & Sub-national & Across Government \\
\hline $\begin{array}{l}\text { Mandatory } \\
\text { installation of } \\
\text { 'smart meters' } \\
\text { in Victoria, } \\
\text { Australia }\end{array}$ & $\begin{array}{l}11 \text { interviews and } \\
\text { public documents }\end{array}$ & Sub-national & $\begin{array}{l}\text { Government and } \\
\text { External Actors }\end{array}$ \\
\hline
\end{tabular}

\section{The Four Policy Examples}

Zero Carbon Homes - UK

In December 2006 the UK Labour Government published a consultation document setting out plans to move towards zero carbon in new housing by 2016. The policy continued under the Coalition government in 2010 but it was amended to balance the zero carbon target with the stimulation of growth in the house building industry. The concept of 'Allowable Solutions' was thus introduced to include off-site carbon reductions. After 9 years, and one year before it was scheduled to come into effect, the Conservative government announced that it no longer intended to proceed with the policy, citing its aim to reduce net regulation and stimulate house building activities. The policy is of interest for our purposes for two reasons. First, it involved several years of intense collaboration between different public and 
private stakeholders facilitated by a public-private organisation - the Zero Carbon Hub allowing us to investigate the construction of memory amongst hybrids of actors. Second, these deliberations were underpinned by considerable research and development into the technical dimensions of the policy. This technical knowledge has considerable value beyond simple lessons learned, and forms a central part of what actors now 'remember' of the process.

\section{Mandatory installation of 'smart meters' in Victoria}

The Advanced Metering Infrastructure (AMI) programme in the Australian state of Victoria was agreed upon in 2006, and implemented in the period 2009-2013. The AMI programme involved the mandatory installation of so-called 'smart meters' - communications-enabled digital electricity meters - in every household and business in the State of Victoria. It was subject to widespread criticism: there were large increases in customer bills, escalating installation costs, and a range of technical problems. This resulted in a number of consumer protests, including the formation of a 'Stop Smart Meter Australia' protest group as well as a political party - 'People Power Victoria' - with the sole mandate of stopping the implementation of smart meters.

The Victorian AMI programme highlights the challenges inherent in successfully constructing and leading complex collaborative projects. The private sector played an integral role in the AMI programme delivery. Utility distribution companies were the main type of organisation contracted to implement the AMI programme, with the state government providing oversight. Crucially, it was the nature of this relationship - and the lack of public sector leadership - that was criticised heavily by the Victorian AuditorGeneral, who was called in to review the AMI in 2009, and again in 2015. The institutional memories held about the project centre around this negative perception. Other Australian states examining options for introducing smart meters have consciously used the Victorian experience as a model of what not to do.

\section{The 'Justice Sector' in New Zealand}

From 2008, five New Zealand agencies: The Ministry of Justice, the New Zealand Police, the Department of Corrections, the Crown Law Office, and the Serious Fraud Office became collectively known as the 'Justice Sector'. This collection of agencies has worked collaboratively by setting strategy, pooling funding to seed new innovations, and coordinating delivery. Collectively the five agencies employ 23,000 people and are responsible for several billion dollars of expenditure. The justice sector is comprised of agencies with regimented, hierarchical cultures. Their method of collaboration reflects this: monthly meetings of agency chief executives, fortnightly meetings of deputy-chief executives, formal terms of reference, papers, motions, minutes, et cetera. The justice sector is considered by public servants to be one of the most effective attempts at cross- 
agency collaboration in New Zealand (see, for example, Scott and Boyd, 2017). The way it captures and communicates information provides important insights into how actors can create memories across departments without being restrained by traditional siloes.

\section{Family Violence Action Plan - Tasmania}

In 2015, Rosie Batty was made Australian of the Year for her outspoken advocacy on behalf of the victims of domestic violence. Her leadership galvanized a national conversation, and in August 2015 the Tasmanian Government pledged over \$25 million for a new statewide action plan to tackle family violence. The release of the plan was the culmination of a rapid eight-week policy development process, undertaken after state government departments and external stakeholders had set up bespoke institutional structures to deliver the plan. This included a dedicated cabinet sub-committee, a committee of the heads of the relevant agencies who met weekly throughout the process, and a working group from across government that were physically located together for two days a week while they worked on the plan. This kind of collaboration within government was further supported by an external consultative group, built from existing connections.

\section{Key findings from across the policies}

Table 3 below captures the ways in which memories were meaningfully operationalised to prevent memory loss across our four policy examples; themes which are explored through discussion of our empirical findings below.

TABLE THREE: EMBEDDING DYNAMIC, ACTOR-CENTRED MEMORIES IN INSTITUTIONAL PROCESSES

\begin{tabular}{ll}
\hline \hline 'Dynamic' Institutional Memories & Operationalised \\
\hline \hline Collaborative, Whole-of-Government & $\begin{array}{l}\text { Policy processes contain a mixture of 'old } \\
\text { hands' and newer talent, drawn from across } \\
\text { government, allowing memories to be } \\
\text { dispersed in an iterative process }\end{array}$ \\
Formative - an iterative conversation & $\begin{array}{l}\text { Forum 'occasions' become institutionalised } \\
\text { and augmented to ensure that a plurality of } \\
\text { voices is heard. }\end{array}$ \\
Held in common across hybrids of actors & $\begin{array}{l}\text { Physically locate people together in 'hubs', } \\
\text { 'taskforces' or 'steering groups' for portions } \\
\text { of the policy process } \\
\text { A 'Wikipedia' model of memory that }\end{array}$ \\
combination of fresh perspectives, individual & $\begin{array}{l}\text { captures and links key public documents so } \\
\text { that they are easily searchable and editable } \\
\text { agency and shared stories. }\end{array}$ \\
\hline \hline
\end{tabular}


The examples illustrate how narratives become embedded in institutional processes and practices, with actors combining documentary records and files with their own memories of what happened. What emerges over time are collective stories that frame past events as a success or failure. But, while their embedded nature implies path dependence, we caution that they nevertheless remain open to change as actors reinterpret the degree of success or failure in light of new information and events. It is this ability to recast memories that renders them dynamic

To illustrate the ways in which policy learning can become institutionalised as memories through this approach, we set out below a discussion of how a dynamic form of institutional memory manifested itself in each example.

\section{From Siloed Memories to Collaborative Conversations}

Across the four policy examples, interviewees were at pains to stress that collaborative approaches - either internally in government or with external actors - require civil servants to be willing to come out of their siloes. This is of course fully in keeping with the existing literature on collaborative governance. But for our purposes here, it also provides an important hint that actors have to find ways to remember at a whole-of-government level if they seek to capture the learnings from these collaborations. Equally, as our examples reveal, for some types of organisation the dispersion of memories through actors occurs within what remain fairly rigid institutionalised practices.

For example, the Justice Sector in New Zealand addressed the problem of memory by attempting to recreate the model commonly used for storing knowledge in agencies - a centralised repository. The agencies all contributed employees to a co-located sector secretariat (or 'backbone function', Kania and Kramer 2011). This secretariat was proportionally larger than for other collaborative efforts in the New Zealand public sector. Interviewees reflected on the hierarchical and procedural nature of the agencies involved, and suggested that this drove a tendency toward formal documentation and fidelity to the planned governance processes.

The Justice Sector was led by several governance groups that met regularly and followed a regimented format. When asked about how memory was retained despite staff turnover, one manager responded:

I'm not certain what the answer is, but perhaps I'd go back to the integrity of those processes. The more you can solidify processes that outlive given personalities, then so long as everybody doesn't change at once you've got a chance that the 
process and "the way things are done around here" endures beyond a given individual. (Interview with executive level public servant, November 2016)

Interviewees reflected that the reliance on process and procedure may not be appropriate in all cases:

Every sector's got different drivers [and] operates in a different context. So it needs to work out what are the things that will pull it together, what are the things that will keep it together, and what are the things that will transcend the personal relationships over time? When you do that you're halfway there anyway. (Interview with executive level public servant, November 2016)

The key point, therefore, is that despite attempts to retain an older, more 'static', form of memory in the new collaborative arrangement, this mode of operation can only go so far. One solution is to make sure that every policy process contains a mixture of 'old hands' and newer talent, drawn from across government, allowing memories to be dispersed in an iterative process. Reflecting on the Tasmanian example, one respondent argued:

I guess that's the benefit of having a mixture of people in organisations, some of which are new and fresh ... and not being drawn down by the past, and [some] people who've been doing things for a long time and have that experience - the "old hands". (Interview with executive level public servant, May 2016)

Such trends are even more pronounced in our material where collaboration includes non-government actors. In the Victorian AMI case, which was the first time this technology had been rolled out in a deregulated market, at the outset there was little memory to draw on. So, government heavily relied on the private sector utilities and metering companies for their expertise and judgment, including their experience and learning in other jurisdictions. The collaborative conversations were about government learning from these private sector actors, rather than vice-versa, as an interviewee heavily involved in the AMI Program explained:

The fundamental problem in all energy policy ... is that the industry has all the expertise. The government doesn't. The regulator doesn't. The consumer sector doesn't... It's an unbalanced thing. (Interview, Manager in the consumer advocacy sector, November 2016).

The UK Zero Carbon Homes example is similar, in that it involved the harnessing and testing of new technologies to achieve building sustainability. Much of this work was undertaken by the Zero Carbon Hub, jointly funded by government and industry. The civil service was one actor in the process but much of the memory resides in the sector: 
On the whole an ambitious civil servant prides themselves on acquiring knowledge of an area and then rapidly moving on. It's part of the way you get promoted. So even if you didn't have the kind of massive reductions we've all experienced in our civil service, you would still have an issue of retaining memory. That's why I say I think that it's much easier for people who are experts to pursue their expertise through other organisations [such as arms-length or peak industry bodies]. (Interview, former senior civil servant, May 2017)

The key point is that while there is no shortage of documentation, the position churn within the civil service means that the longest memories necessarily reside elsewhere, usually in the sector and arms-length bodies. Traditional static conceptions of institutional memory do not provide tools for effectively capturing this kind of dispersed memory, despite its centrality in practice to processes of policy learning.

\section{From Summative Evaluations to Formative Iterations}

As the interview data on 'whole-of-government' approaches bears out, the way in which memory manifests itself is as much through conversation as through accessing formal evaluations that are kept on file. As one Tasmanian public servant, who was brought into the project at the start of the implementation phase, noted: it's the combination of conversation and documentation together that creates lasting memory:

I think definitely there was...person to person transfer [of knowledge]. That's not surprising, both from leaders within the organisation and ... also peers from outside the organisation who have worked on the policy. ... It's also been around the project management and the documentation associated with the policy, being able to trawl back through previous meetings and points of decision. (Interview, Executive level public servant, May 2016)

In the New Zealand example, experiences were recorded with military precision, reflecting the established cultures of the various agencies that together constituted 'the Justice Sector':

Because we had a military guy running things, everything was written down; everything was chronicled. (Interview, Executive level public servant, November 2016).

However, even in this context people found their way through observing the behaviours of others: 
There's [also] the informal aspect, whereby new people arrive, they see how things work, they see how the machine operates and they find their way within it. (Interview, Executive level public servant, November 2016)

A dynamic conceptualisation does not ignore documentary material, but rather combines it with informal conversation. Indeed, informal conversations are generally the starting point when actors from across government are looking for past examples of success. To take the Tasmanian example:

We have seen those person-to-person contacts about: "You guys did that. What was that like? What did it look like? What did you do?" (Interview, Executive level public servant, May 2016)

Having a formative conversation also allows actors to reflect on whether the templates of past success or failure are actually appropriate to the new policy challenge they're confronting. It provides the basis for the iterative conversations about how memory can be used going forward, rather than being trapped by a past success.

It's always a balance too because you don't want to fall into the trap of saying "I remember 10 years ago we tried this and it didn't work then and it isn't going to work now". ... It's also useful to have fresh sets of eyes on...particularly the wicked problems, [because] if the solutions were understood and memorised then they wouldn't be wicked problems. (Interview, Executive level public servant, May 2016)

A solution to memory loss that takes informal conversation seriously would seek to provide forums for stories about policies to be told from a range of perspectives, including both senior and junior officials, and including organisations from outside of government, where relevant. The Australian Public Service now has secretary-level committees that discuss whole-of-government issues on a regular basis. We are suggesting that a similar approach could also work vertically in specific policy areas. In this way Linde's (2008) 'occasions' become institutionalised and augmented to ensure that a plurality of voices is heard.

\section{From government departments to collaborative hybrids}

A collaborative environment requires that memories are constructed across departments and sectors. As discussed, one example of this type of approach is the Zero Carbon Hub in the UK, which was established as a non-profit organisation to take day-to-day operational responsibility for achieving the Zero Carbon policy by 2016. When this policy was abandoned in 2015 money was set aside to maintain an e-repository of the Hub's policy and 
technical publications. The people who staffed the Hub are also still working on these issues, as the below quote illustrates:

When the Hub finished, I formed another company called The Buildings Hub, and that still runs today. It's still doing much of the work that the Zero Carbon Hub did, with the same operational directors, the same technical director, the same project director, [and] myself as managing director. We still carry on that work. (Interview, Former Director of the Zero Carbon Hub, February 2017).

The point is that in this case much of the memory resides in the sector rather than strictly with the responsible government department. A more extreme manifestation of 'outsourcing' to the private sector is observed in the Victorian AMI case, wherein the state government at the outset completely delegated the implementation of the policy to private sector utilities, as an interviewee explained

I think government's view of the program at the time [2006-2012] was that you can leave it completely to industry. It was a mandated roll out [of smart meters] by [the electricity] distributor, "They can do the whole thing themselves - we don't really have to have any involvement." (Interview, Government Policy Officer, November 2016)

It was only from 2012 that a formal government program (with funding) was established, which ran for four years.

There are obviously strengths and limitations in thinking of memory as sectoral rather than governmental. In some respects, industry has more incentive to remember than government. Indeed, Ministers recalled that when they first came to a particular policy area they often felt that key lobbyists knew more about the topic than they did, as this former UK housing Minister reflects:

When a minister changes, all the lobbyists ... will immediately seek to engage with that minister in one way or another, and a sensible minister will want to do the same. ... You can't move an inch in [some] policy areas without hearing exactly what people think about that, and also advocating the things that you should be doing, in their opinion. (Interview, Former Housing Minister, March 2017).

In this view, entrenched interests are the vehicle for institutional memory. But, incentives alone are not always enough, as this reflection from someone closely involved in the UK's zero carbon homes policy reveals:

Well, the trouble is from the private sector's perspective...they just think about it as how it affects them as an individual company. I mean, UKGBC [UK Green 
Building Council] arguably would be a good repository for this information, but we [would] need funding and somebody to pull it all together and the time to do it.... At the moment it's kind of all fresh in our brains so we're not seeing the need to write it down. (Interview, Peak body representative, November 2016).

One way around this is to physically locate people together, as was the case with the Zero Carbon Hub, and our New Zealand and Tasmanian examples. Obviously co-location is much easier when just dealing with government departments, as in the New Zealand example where policy officials working to support the formal governance groups were relocated to the offices of the Ministry of Justice, and the Tasmanian case where senior civil service leaders met weekly. Those involved in co-location generally spoke highly of its utility. For example, in the Tasmanian example, officials from across multiple agencies physically relocated to work together for two days a week across the eight-week policy creation period, as an interviewee explains:

It was a way of enabling a combination of formal meetings that took place, but also that informal interaction that is obviously really important. As you're working on something very intensely you're able to be deep in your work, but then step out of that and go, "I need to talk to [name omitted] from the police about this particular question," or, "Where do I get this information, how do I source that data," and she was there and able to do that physically. (Interview, Executive level public servant, May 2016)

\section{From 'Files' to Living Memory}

At the core of a dynamic conceptualisation of institutional memory is the idea that static files can only be brought to life by actors seeking to use them as a formative tool. As noted by one Tasmanian interviewee, documentation by itself can see memories quickly fade, even when the approaches described would be useful in a new policy process:

When we were reflecting on how it had gone, one of the task force members from our [communications] area said, "We had a bit of a check list for the bushfire task force, ... maybe we should have looked at that before starting," and I thought, "Mmm, [that] would have been quite useful." So we were really bad at taking our learnings and documenting, and then remembering that we've got them and pulling them out and using them.... [We had] all sorts of amazing little tools and techniques, but did we use [our records]? No. (Interview, Executive level public servant, May 2016)

The answer, suggested another, lies in the importance of utilising 'lived experience' as memory to buttress documentary materials: 
As an agency, this department has invested a fair bit in theory and practice guides around collaboration - we've produced frameworks for collaboration in government. But, in my own experience, unless you've lived it and breathed it yourself, you might own it at a conceptual level, but you don't necessarily own it at an emotional and behavioural level. (Interview with executive level public servant, May 2016)

One government interviewee in the AMI case captured nicely this distinction between formalised repositories about a government program and 'lived experience':

Yes, there were records that were created ... there were documents ... which actually listed the institutional memory ... So I would say that if anyone wanted to know what was going on there, the information was definitely available to them. It wasn't just 'shut down and walk out the door'. [But] in terms of that full and frank discussion, who do you have that with? In terms of talking about what had happened and what hadn't happened? ... I don't know. (Interview, Senior Policy Officer in Victorian Government, November 2016).

While Pollitt (2008) notes that turnover has damaged memory within institutions, it also provides an opportunity for lived policy experiences to be propagated. New Zealand has attempted to spread the lessons from collaborative success by moving leaders from other departments into the justice sector to experience collaborative governance arrangements, and to move leaders from the justice sector to other parts of government where closer collaboration is required. Bringing together different experiences was seen as contributing to new leadership practices.

I think everybody brings something different depending on where they've come from. We had the good fortune of being led by someone who was a career diplomat ... so he had a particular way of working with others. Working for him, ... there was a former military guy [and] he had a particular way of doing things. I'd spent the better part of a decade in the treasury, so [I] learned about how the game works. Everybody brings their own different perspectives, and then it's a matter of trying to find something that works for everyone among those different perspectives. (Interview, Executive level public servant, November 2016)

One source of 'lived' memory is memoir and institutional history. Numerous interviewees in the UK example suggested a memoir by former MP Nick Raynesford, for example, even if they had not read it themselves. Similarly, respondents expressed enthusiasm for academics documenting these types of stories, but conceded they were unlikely to read anything outside their specific area of interest. Interviewees also cited other e-repository type models as best practice, including parliamentary committee reports and Hansard debates. What many outside government seemed to favour - and indeed some in 
the UK case explicitly endorsed - was a 'Wikipedia' model of memory that captured and linked key public documents so that they were easily searchable online. And as users of Wikipedia know, part of it's appeal is that it exists as a live conversation, with entries constantly being updated and upgraded. In contrast, actors within government agencies with more established institutional cultures - such as in the Justice Sector in New Zealand were much more likely to stick with ensconced traditions of record-keeping through maintaining strong secretariat functions.

\section{Conclusion}

Our four examples provide insights into the myriad ways in which institutional memories are created and retold. Interview responses show a spectrum of practice, with various degrees of reliance on a mixture of informal story-telling and formal documentation that emerges from the more traditional types of departmental processes. We are not suggesting that these mechanisms are exhaustive or will work the same way in every policy setting. Nor are we suggesting that bureaucracies can or should simply give up formalised ways of remembering through files, minutes and other memory aids. Documentary memories remain necessary for modern institutions; our argument is simply that they are not sufficient in themselves as a way of storing memory. Whilst they remain vital, they do not exist as some objective form of knowledge waiting to be retrieved by actors. Rather, the research presented here suggests that actors are using socially constructed forms of memory in tandem with existing static memory structures and procedures. Whilst this is not a new occurrence, we suggest that with increasing collaborative governance it has become more central. Moreover, it is evolving a form of practice that has left current static theories of institutional memory in its wake. This article represents one set of arguments about how the scholarship on institutional memory might be able to catch up.

It also points to potential avenues for future research. First, how can we extend the lifespan of memories through the stories that actors tell? The data from our research suggest that even dynamic stories can slip away into the unconscious over time and therefore can be just as unlikely to be retrieved as the thirty-year-old files in a department's archives. This becomes particularly difficult when memories are held between hybrids of public and private actors. Second, how can living documents containing memories best be shared and built across hybrids of actors, without contravening the need for policymaking processes to remain in camera until they have reached political decision points? Third, there is a need for significantly more empirical research to more systematically test how memory is currently being captured in different types of organisations and through varying structures. For example, are dynamic processes for retaining and sharing memory different in public sector organisations operating at arms length from government, compared to central agencies operating at the heart of the executive? 
Finally, the examples from Tasmania, Victoria, and to some extent New Zealand, suggest that within smaller jurisdictions there is a greater sense of connectivity between government agencies, and with external actors, based on long experience of having worked together. That in itself means that when groups of actors are confronted with new policy problems, they have a shared repertoire of memories to build on and the established networks necessary to iteratively shape new policy responses. As one Tasmanian interviewee suggested:

When we need to take collective action, we don't send each other letters and wait for a response, we get on the phone. We see each other in the street. So it makes that sort of collaborative leadership easier because we have made a personal and professional investment in each other over time. (Interview, Executive level public servant, May 2016).

Further research is needed to establish whether the modes of memory practiced within smaller policy communities can also be scaled up to meet the needs of larger jurisdictions.

It is also worth considering the potential path dependent effects that may see 'bad' memories retained and propagated because of the vested interests of some actors in a particular version of the 'story.' We only need to consider the ready embrace by British authorities of the dossier alleging the presence of weapons of mass destruction in Saddam Hussein's Iraq to appreciate that narratives can be misleading. Czarniawska's point about the plausibility of the 'story' being testable suggests one avenue for combatting memory gaps or false memories, but more research is needed on what happens at the point of challenge and which factors determine which memory is held 'true' in a given situation.

Despite these important caveats and disclaimers, ultimately we argue that the increasingly networked context in which policy is currently being made, defined as it is by increased speed and collaboration, requires a more consciously dynamic conceptualisation of institutional memory that both better captures how the past is currently being recorded in different governing contexts, and provides an opportunity to think through how these practices might be strengthened. Rather than a return to a past way of operating, a dynamic actor-centred conceptualisation offers a way of reinterpreting past traditions into the present. In doing so we shift the scholarly focus: from institutional memory to institutional memories.

\section{References}

Alford, J. and J. O'Flynn. 2012. Rethinking Public Service Delivery: Managing with External Providers. Basingstoke, Hampshire: Palgrave Macmillan. 
Bartenberger, M. and D. Sześciło. 2016. "The Benefits and Risks of Experimental CoProduction: The Case of Urban Re-Design in Vienna." Public Administration 94 (2): 509-525.

Bell, S. 2011. “Do We Really Need a New 'Constructivist Institutionalism' To Explain Institutional Change?" British Journal of Political Science 41: 883-906.

Bennett, C.J. and M. Howlett. 1992. "The Lessons of Learning: Reconciling Theories of Policy Learning and Policy Change." Policy Sciences 25 (3): 275-294.

Bevir, M. and R.A.W. Rhodes. 2010. The State as Cultural Practice. Oxford: Oxford University Press.

Bouckaert, G. 2017. "Taking Stock of 'Governance': A Predominantly European Perspective." Governance 30 (1): 45-52

Cairney, P. 2009. "The Role of Ideas In Policy Transfer: The Case of UK Smoking Bans Since Devolution." Journal of European Public Policy 16 (3): 471-488.

Carey, G. and B. Crammond. 2015. "What Works in Joined-Up Government? An Evidence Synthesis." International Journal of Public Administration 38: 1020-1029.

Corbett, J., and C. Howard. (2017) "Why perceived size matters for agency termination." Public Administration 95(1): 196-213

Czarniawska, B. 1997. Narrating the Organization: Dramas of Institutional Identity. University of Chicago Press.

Czarniawska, B. Narratives in social science research. Sage, 2004

Duncan, R. B., and Weiss, A. 1979. "Organizational learning: Implications for organizational design." In B. M. Staw (Ed.), Research in organizational behaviour (Vol. 1). 75-124. Greenwich, JAI Press.

Dunlop, C.A. and C.M. Radaelli. 2013. "Systematising Policy Learning: From Monolith To Dimensions." Political Studies 61 (3): 599-619.

Elston, T. 2014. "'Not So 'Arm's Length': Reinterpreting Agencies in UK Central Government." Public Administration 92 (2): 458-476.

Fischer, F. 2003. Reframing Public Policy: Discursive Politics and Deliberative Practices. Oxford: Oxford University Press.

Hay, C. 2011. "Interpreting Interpretivism Interpreting Interpretations: The New Hermeneutics of Public Administration." Public Administration 89 (1): 167-182. 
Hendriks, C M. 2009. "The Democratic Soup: Mixed Meanings of Political Representation in Governance Networks." Governance 22 (4): 689-715

Hood, C. and M. Lodge. 2006. The Politics of Public Service Bargains: Reward, Competency, Loyalty-And Blame. Oxford: Oxford University Press.

Kania, J. and Kramer M. 2011. "Collective Impact." Stanford Social Innovation Review Winter 2011: 36-41.

King, A. and I. Crewe. 2013. The Blunders of Our Governments. London: Oneworld.

Lindblom, C. 1959. "The Science of Muddling Through." Public Administration Review 19 (2): 79-88.

Linde, C. 2008. Working the Past: Narrative and Institutional Memory. Oxford: Oxford University Press.

Lijphart, A. 1971. "Comparative Politics and the Comparative Method." American Political Science Review 65 (3): 682-693.

Lindquist, E.A. and C. Eichbaum. 2016. "Remaking Government in Canada: Dares, Resilience and Civility in Westminster Systems." Governance 29 (4): 553-571.

Lowndes, V. and M. Roberts. 2013. Why Institutions Matter: The New Institutionalism In Political Science. Basingstoke: Palgrave Macmillan.

March, J. G. 1972. "Model bias in social action." Review of Educational Research. 44: 413429.

Marsh, D. and R.A.W. Rhodes. 1992. Policy Networks in British Government. Oxford: Clarendon Press.

Marsh, D. 2011. "The New Orthodoxy: The Differentiated Polity Model." Public Administration 89 (1): 32-48.

Nystrom, P. C., \& Starbuck, W. H. 1984. "To avoid organizational crisis, unlearn." Organizational Dynamics, 12: 53-65.

Osborne, S. (ed.). 2009. The New Public Governance? London: Routledge.

Pierson, P. 2004. Politics in Time. History, Institutions and Social Analysis. Princeton: Princeton University Press. 
Pierson, P. 2000. "Increasing Returns, Path Dependence, and the Study of Politics." American Political Science Review 94 (2): 251-267.

Pollitt, C. 2009. “Bureaucracies Remember, Post-Bureaucratic Organizations Forget?" Public Administration 87 (2): 198-218.

Pollitt, C. 2008. Time, Policy, Management: Governing With The Past. Oxford: Oxford University Press.

Pollitt, C. 2007. "Chapter 9 Time Out?" in K. Schedler and I. Proeller (eds), Cultural Aspects of Public Management Reform (Research in Public Policy Analysis and Management, Volume 16) Emerald Group Publishing Limited, pp. $231-245$.

Pollitt, C. 2000. "Institutional Amnesia: A Paradox of the 'Information Age'?” Prometheus 18 (1): 5-16.

Rhodes, R.A.W. 1997. Understanding Governance: Policy Networks, Governance, Reflexivity and Accountability. Buckingham: Open University Press.

Rhodes, R.A.W. and A. Tiernan. 2014. Lessons of Governing. A Profile of Prime Ministers' Chiefs of Staff. Melbourne: Melbourne University Press.

Rhodes, R.A.W. 2011. Everyday Life in British Government. Oxford: Oxford University Press.

Rhodes, R.A.W., J. Wanna and P. Weller. 2009. Comparing Westminster. Oxford: Oxford University Press.

Richards, D. and M. Smith. 2016. "The Westminster Model and the 'Indivisibility of the Political and Administrative Elite': A Convenient Myth Whose Time is Up?" Governance 29 (4): 499-516.

Schmidt, V.A. 2008. "Discursive Institutionalism: The Explanatory Power of Ideas and Discourse." Annual Review of Political Science 11: 303-326.

Schmidt, V.A. 2010. "Taking Ideas and Discourse Seriously: Explaining Change through Discursive Institutionalism as the Fourth 'New Institutionalism'." European Political Science Review 2: 1-25.

Schon, D. A. 1983. The Reflective Practitioner. New York: Basic Books.

Scott, R. J., and Boyd, R. 2017. Interagency Performance Targets: A case study of New Zealand's Results programme. Washington DC: IBM Business of Government. 
Smullen, A. 2010. "Translating Agency Reform Through Durable Rhetorical Styles: Comparing Official Agency Talk Across Consensus and Adversarial Contexts." Public Administration 88 (4): 943-959.

Stark, A. 2017. "The Shelf-Life of Public Policy: Institutional Memory and Amnesia in Four Westminster Systems." Paper Presented at the Political Studies Association Annual Conference, Glasgow, April 2017.

Sullivan, H. 2015 "Democracy and hybrid governance in Australia." Meanjin 74(3): 120-122 Walsh, J. P., and Ungson, G. R. 1991. "Organizational memory." Academy of management review, 16(1): 57-91.

Wettenhall, R. 2011. “Organisational Amnesia: A Serious Public Sector Reform Issue." International Journal of Public Sector Management 24 (1): 80-96. 